\author{
Wojciech Szczepanek \\ inż. \\ student Politechniki Wrocławskiej \\ Wydział Budownictwa Lądowego i Wodnego \\ 234304@student.pwr.edu.pl
}

DOI: 10.35117/A_ENG_21_02_02

\title{
The analysis of safety and traffic conditions on Orląt Lwowskich Square in Wrocław
}

\begin{abstract}
For some years road infrastructure has been beeing rebuilt and expanded in Wrocław. There are a lot of enterprises connected with it which aim is to encourage citizens to use public transport and also improve traffic conditions in the area of the whole city and adjust it to modern standards. This article refers to the analysis of the influence of the newly built. "TAT" rout level 1 in Wrocław on conditions in The Orląt Lwowskich square area. All elements which were rebuit, not only because of the new tramway but also because of regarded changes due to safety and increasing of road capacity, were taken under considaration. The condition before rebuilding, implemented changes and other ideas which could be applied were analysed. In the summary of this article advantages and disadvantages of individual solutions were presented with their description.
\end{abstract}

Keywords: Traffic analysis; Safety; Road capacity; Tramway; Rebuilding; Traffic conditions

\section{Introduction}

In recent years, the road infrastructure in Wrocław has been reconstructed and expanded. This is due to the high volume of traffic within the city, which results in numerous congestion, i.e. queuing of vehicles in the intersection network. One of the main projects related to the improvement of traffic conditions is the construction of the "TAT" tram and bus route, which is divided into 3 stages. Stage I covers the construction of a line from the intersection of Orląt Lwowskich square - Piłsudskiego Street- Podwale Street to the Business Park. Stage II is to lead from the Business Park to Rogowska Street. The last stage of the third stage will run along Rogowska Street and is to be ended with a loop within the Nowy Dwór railway station. The construction of "TAT" aims to reduce the movement of passenger vehicles in the city by encouraging residents to use public transport. Another problem is outdated, ill-considered solutions that do not comply with the regulations, which lead to dangerous road situations. Therefore, the technical parameters of individual areas should be adapted to today's standards. The rest of the article focuses on the analysis of road and traffic conditions as well as the safety of the original geometry of the area. The course of the newly completed investment "TAT" stage 1 for design solutions is also important. The route to be built is to run along separate traffic lanes and to be collision-free to reduce the transit time of buses and trams, which is an additional advantage to resigning from the use of private cars within the city. The analyzed area and the course of the newly built "TAT" route are shown in Figure 1. 


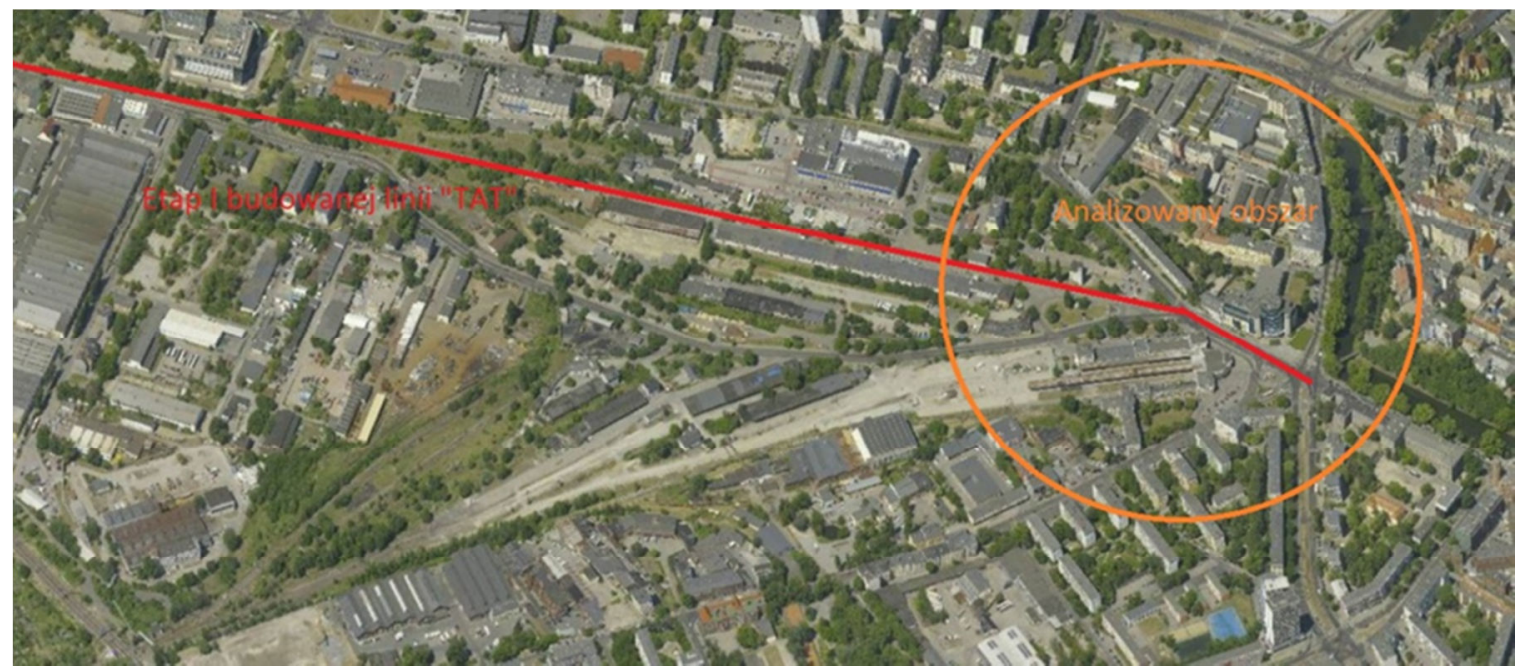

1. The course of the "TAT" route under construction, stage I and the analyzed area marked Source: [9]

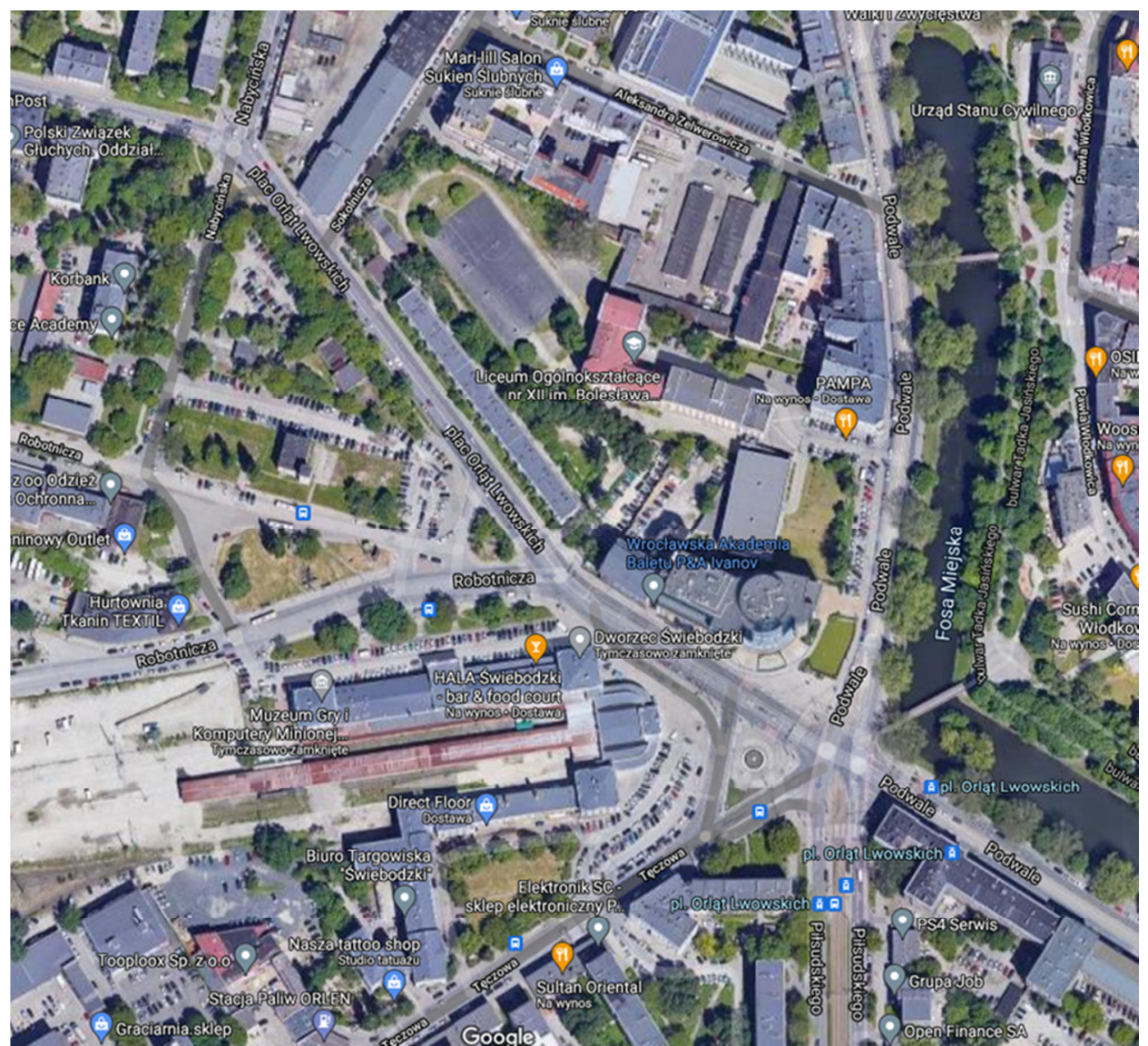

2. Characteristics of the analyzed area from Figure 1

Source: [2]

Analysis of traffic and safety conditions in the area of Orląt Lwowskich square before the reconstruction

Currently, it may seem that the area of Orląt Lwowskich square has been rebuilt to adapt to traffic conditions only to the newly built "TAT" route. The truth is quite different because the area before the reconstruction had dangerous solutions and the capacity was low, so the level of freedom of movement, assessed on the basis of the average loss of time, was at level III and IV for most of the inlets. The described PSR was obtained in the calculation procedure 
that will be presented upon completion [6]. However, it was made on the basis of [4], field observations, and own observations. The [4] used were also used to determine the rush hour, which is determined in 15-minute or 1-hour periods based on the number of vehicles moving in a given time interval through a given section. Four areas were classified as dangerous or with poor traffic conditions.

The first is the eastern entrance of Podwale Street to the intersection of Piłsudskiego Street - Podwale Street- Orląt Lwowskich square shown in Figure 3. The biggest problem was the bus and tram stop located on the sidewalk on the right side, looking from the inlet. In Figure 3. Due to the location of the tram line separated by two traffic lanes with the P-17 marking "stop line", pedestrians had to walk $6 \mathrm{~m}$ in order to get safely from the stop to the communication vehicle and vice versa. This was a dangerous situation, as the moving vehicles might not notice the stopping tram and the leaving passengers. The psychological aspect is also important in this situation because the location of the stop near the inlet could make the driver want to accelerate the vehicle in order to be able to pass the green signal before people using public transport leave. In road engineering, the behavior of individual road users is important. Mainly the decisions they make, which the designer should predict and take into account when analyzing or designing solutions. Additionally, getting out of the tram onto the road was difficult due to overcoming a considerable height. Rutting the problem still related to the location of the stop near the inlet is significantly reduced capacity because two lanes during the passage of passengers were blocked, or one when the bus stopped.

The second area is the southern inlet of Piłsudskiego Street, shown in Figure 4, in which the leftmost left lane looking from the inlet side, being a left-hand turn, had a low capacity. It was caused by heavy traffic, where at the specified peak time the number of passing vehicles was 464 and the green signal was 12-15 seconds long. The problem was that the green signal was too short and it was not possible to extend it, as it would require shortening the remaining phases by a few seconds. In addition, the given left-turn required the implementation of an additional phase of the movement, which took additional time of the green signal from the other signaling devices. The possibility of removing this relation would increase the capacity of the remaining inlets. There were also one-way bicycle paths at the edges of the road. Each of them is $1 \mathrm{~m}$ wide, where according to [1] the minimum width for such paths is $1.5 \mathrm{~m}$, and according to [7] the recommended width within the city of Wrocław should be $2 \mathrm{~m}$. It is inconsistent with the guidelines and poses a threat to the safety of bicycles traveling within Piłsudskiego Street.

Another area is the southern inlet of Robotnicza Street within the intersection of Robotnicza Street - Orląt Lwowskich square shown in Figure 5. In this case, the problem is the crossing of two streets at an angle of $60^{\circ}$, which significantly reduces the visibility. According to the regulation [1], the road intersection angle should be $90^{\circ}$, with a deviation of $30^{\circ}$ allowed. This value is significantly too low. The condition of the northwest visibility was also not met, as the trees on the island blocked the field of view at this angle. Additionally, the traffic volume at the inlet was 536 vehicles in the rush hour, while the north-west inlet at Orląt Lwowskich square amounted to 1,227 vehicles, which illustrates poor traffic conditions. Given the characteristics of the area, it can be concluded that all safety conditions should be met.

The last area is the northwest entrance of Robotnicza Street within the intersection of Robotnicza Street - Orląt Lwowskich square shown in Figure 5. The traffic intensity of the inlet of Robotnicza Street turns out to be much smaller than that mentioned in point 3, but the road intersection angle is $48^{\circ}$. This is not in line with the regulation [1] and should be amended. The field of view was limited to the east due to the trees situated by the island and by the angle of the entrance leading to the Orląt Lwowskich square. 
On the basis of the letter [3], road incidents in the area shown in Figure 1 within Orlat Lwowskich square, wherein 2015-2020 there were 11 accidents with 11 injured people and 243 collisions. Their number decreased by almost half compared to the previous years in 2020 due to the change in traffic organization caused by the commencement of the construction of "TAT". In this way, it can be determined that the area required reconstruction due to safety and traffic conditions, and not only due to the construction of a new tram and bus line.

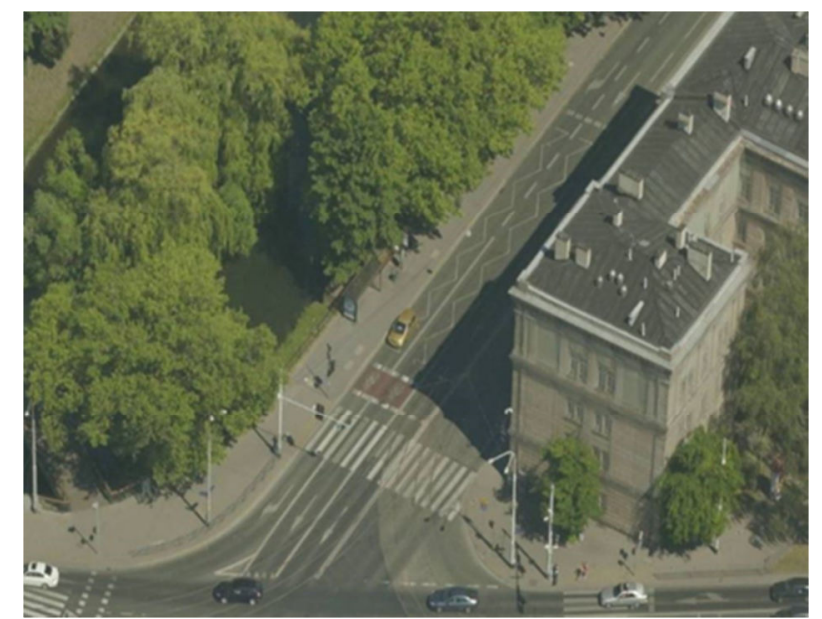

3. East inlet of Podwale Street within the intersection of Piłsudskiego Street

- Podwale Street - Orląt Lwowskich square

Source: [9]

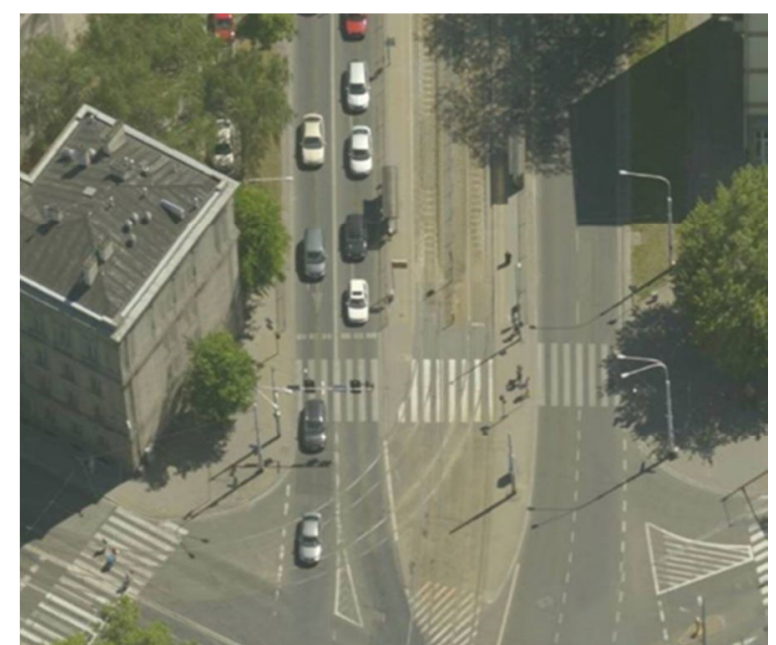

4. The southern inlet of Piłsudskiego Street within the intersection of Piłsudskiego Street

- Podwale Street - Orląt Lwowskich square

Source: [9] 


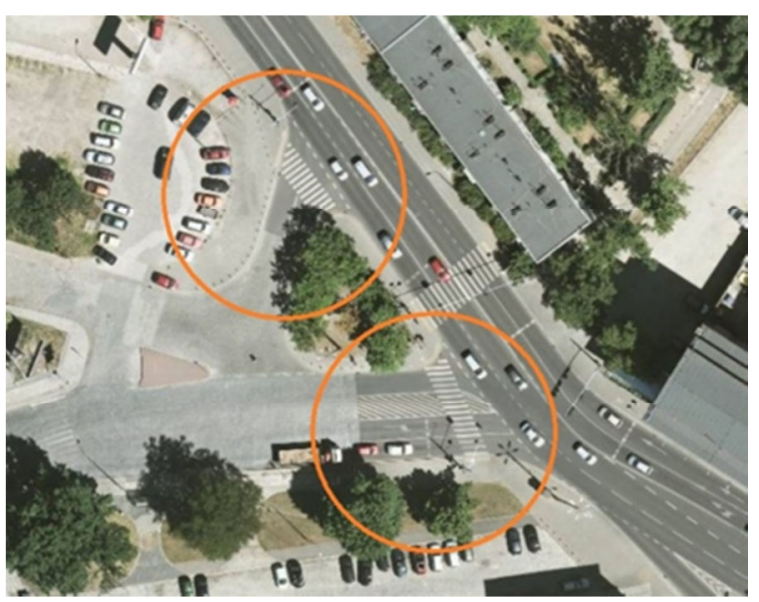

5. South and the north-west inlet of Robotnicza Street

within the intersection of Robotnicza Street- Orląt Lwowskich square Source: [9]

\section{Description of geometric changes after reconstruction and their impact on safety and traffic conditions}

The most important change that influenced the applied geometric solutions within Orlat Lwowskich square is a newly built section of the "TAT" tram and bus line, stage I, shown in Figure 1. It starts at the intersection of Piłsudskiego Street - Podwale Street- Orląt Lwowskich square, where it connects the tramlines with the southern inlet in Figure $\mathbf{4}$ and the eastern inlet in Figure 3. It runs along Orląt Lwowskich square, and then in the area of the former intersections in Figure 5, it turns into Robotnicza Street to the west. Thanks to this solution, the tram and bus line has separate roads. It also reduces the areas of collision with other traffic participants. In particular, the solution of the intersections in Figure $\mathbf{5}$ was influenced by their complete removal. Currently, traffic from Robotnicza Street is only and exclusively towards the intersection of Piłsudskiego Street - Podwale Street - Orląt Lwowskich square, while the traffic from the opposite direction remained unchanged. The area after the reconstruction is shown in Figures 6 and 7. The above-mentioned changes eliminated the problem of an acuteangled road crossing, additionally there is no collision related to the tram line. This eliminates the problem with the concept of throttling traffic, which significantly affects the throughput. The current solution increases both safety and traffic conditions.

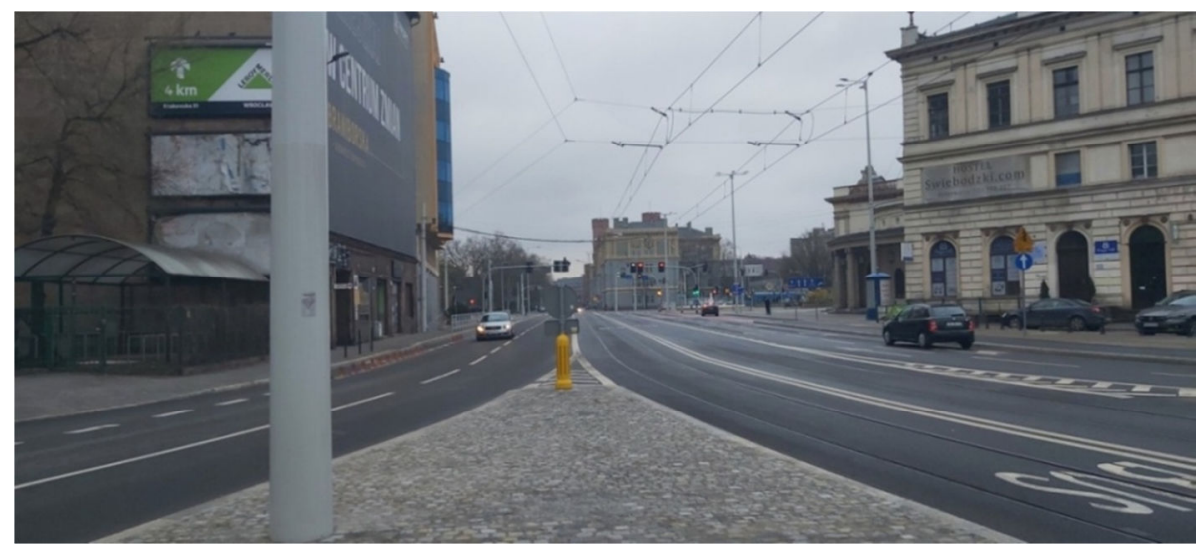

6. The view from the rebuilt area in Figure 5 towards the intersection of Piłsudskiego Street Podwale Street - Orląt Lwowskich square (eastern direction)

Source: [own photo] 


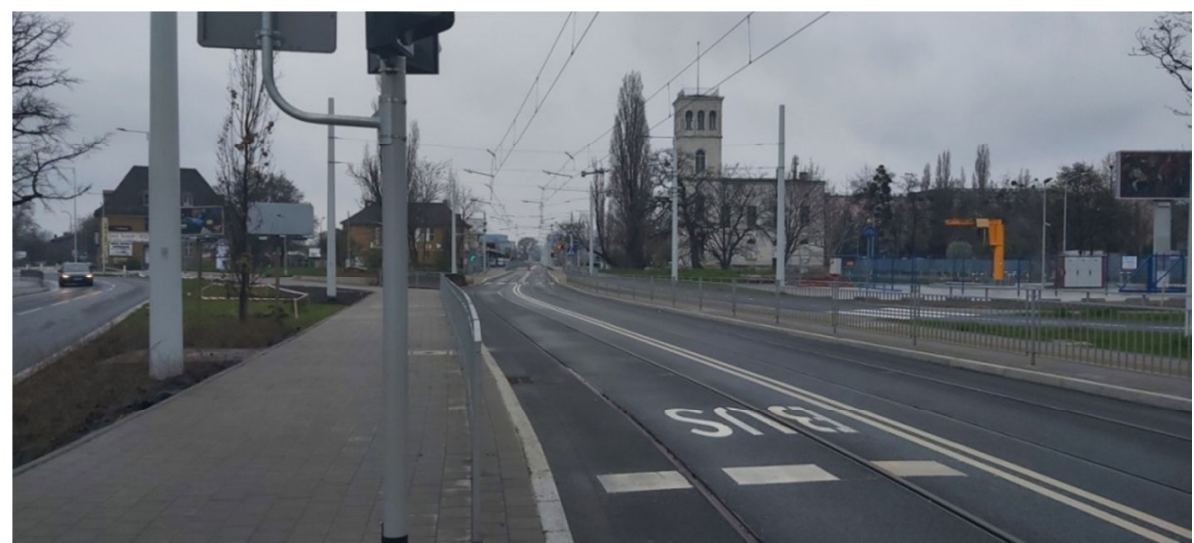

7. The view from the rebuilt area in Figure 5 in the opposite direction to Figure $\mathbf{6}$ (west direction) Source: [own photo]

The eastern entrance to Podwale Street is shown in Figure 3. An island was built on the road axis to which the stop was moved. In addition, there is a bus lane on the tram track. Thanks to these solutions, all passengers' problems when getting off were solved and the inlet capacity was improved. The described area is presented in Figure 8.

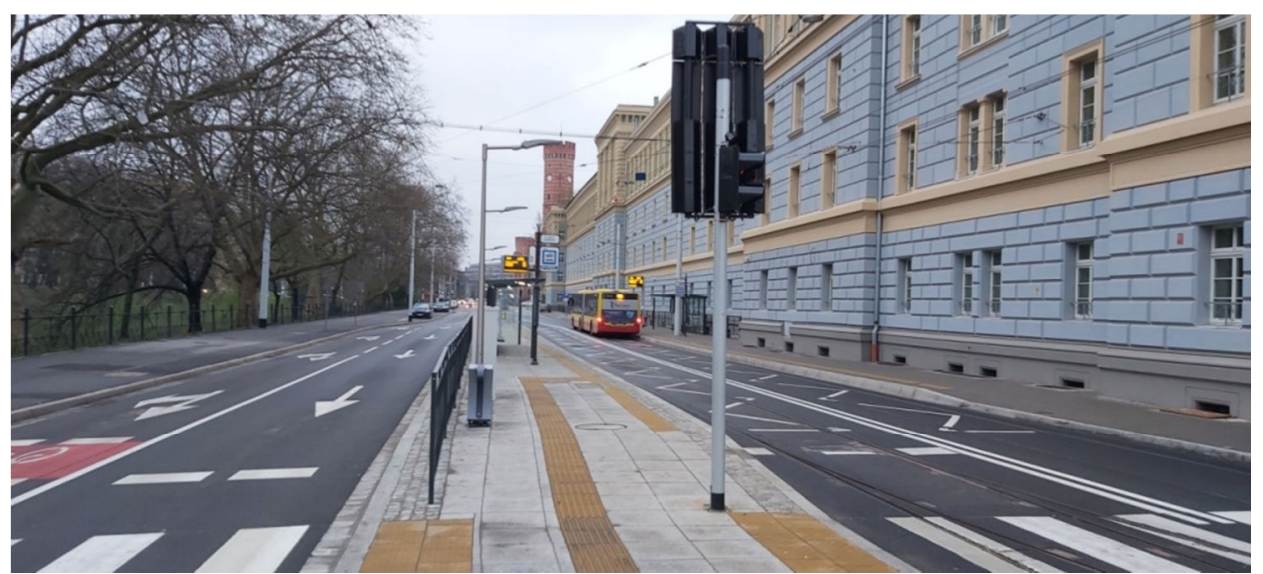

8. View of the eastern inlet of Podwale Street after the reconstruction Source: [own photo]

The construction of the tram and bus line "TAT", together with the solutions used in Figures 6 and 7 in the area in Figure 5, forced the reconstruction of the intersection of Robotnicza Street - Nabycińska Street from Figure 2. Originally, the traffic volume did not exceed 1000 vehicles a day within the above-mentioned area, but after the changes in traffic organization, all participants who previously moved from the north-west through Orlat Lwowskich square are forced to follow Nabycińska Street and only then join the traffic on Robotnicza Street in the southern part to get to the intersection of Piłsudskiego Street Powale Street - Orląt Lwowskich square. In addition, the tram line crosses the described street, and thus forced the creation of traffic lights. The described intersection is shown in Figure 9 before the reconstruction and Figure 10 after the reconstruction. In addition to the use of traffic lights in a critical point, the pavement was rebuilt, the road was widened by one lane and the horizontal and vertical markings were completed. 


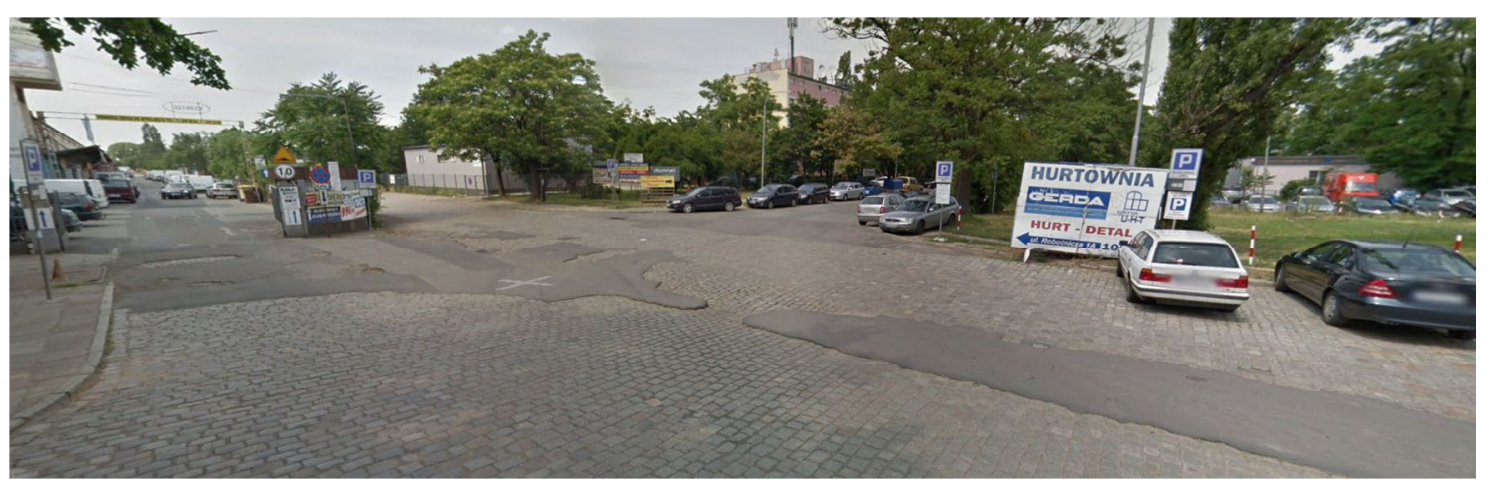

9. View of the intersection of Nabycińska Street - Robotnicza Street before the reconstruction Source: [2]

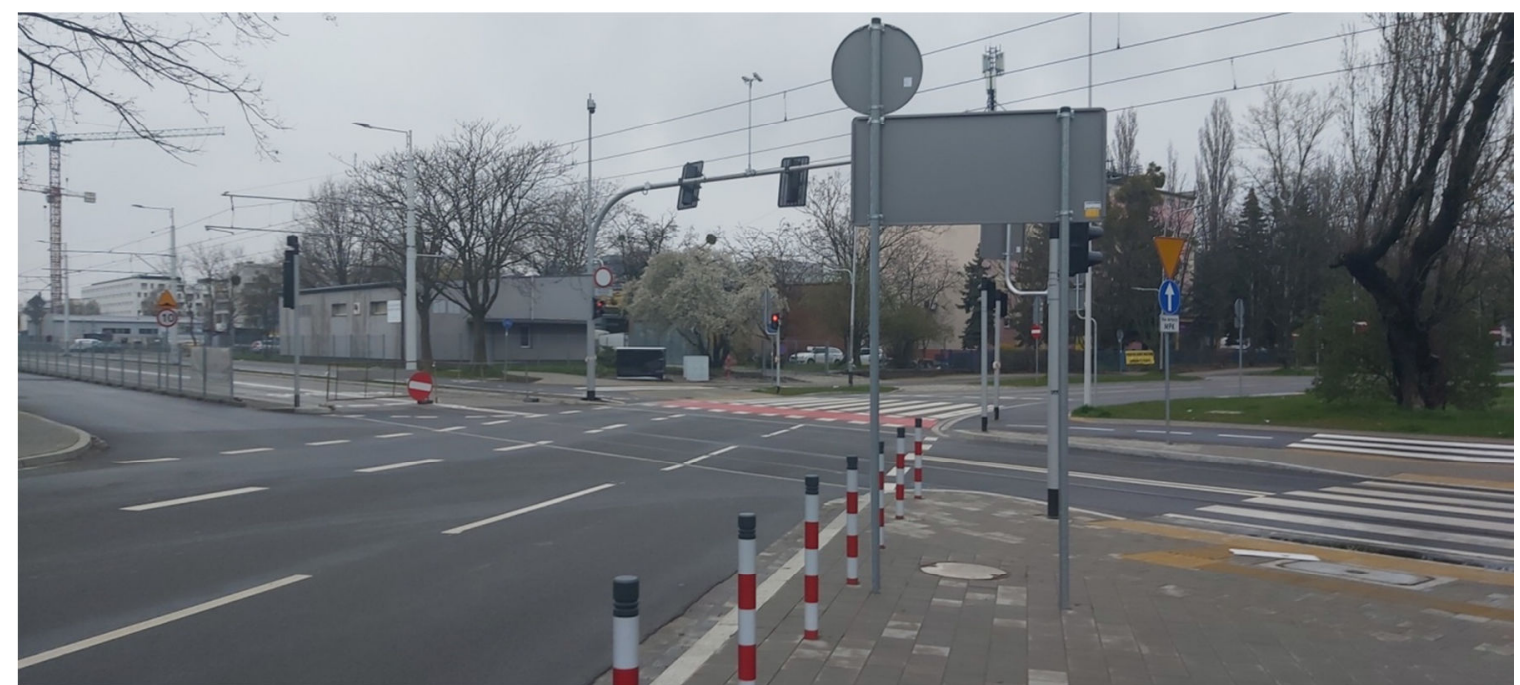

10. View of the intersection of Nabycińska Street - Robotnicza Street after the reconstruction Source: [own photo]

The last significant change is the designated bicycle lanes in Orlat Lwowskich square, a fragment of which can be seen in Figure 6. The constructed 2-meter one-way paths, and locally 2.5-meter two-way paths in accordance with [7]. Also, along the "TAT" route, a separate bicycle path was created on the right, as shown in Figure 7. Originally, bicycle traffic took place on lanes intended for car rolling stock, which at such a high intensity was dangerous for road users and this led to accidents. Current solutions increase safety for cyclists, which encourages the use of a "healthy" means of transport.

\section{Alternative solution}

The solutions used are correct, but there are other options to improve bandwidth and traffic conditions. As part of improving the safety of bicycle traffic, one-meter long green belts could be used to separate bicycle paths from the road. Then, the proposed solutions are presented in terms of improving the traffic of motor vehicles, trams, and buses in the analyzed area from Figure 1. One of the proposals is to lead a left-handed relation on Piłsudskiego Street through an underground passage or a flyover, where the first option is presented in [6]. By eliminating this relation from the traffic light phases, the traffic conditions within the intersection are improved, and the problem of queuing vehicles in the described lane is solved. The disadvantage of the proposed solutions is the high investment cost. In addition, when passing underground, an additional problem is the reconstruction of the underground utilities and the problem with execution due to the high table of groundwater in the vicinity of the city of Wrocław. So it seems that leading a torsion relation on the flyover is a better idea, but the 
problem is the location of the columns on which the structure would be located, due to the lack of space on Piłsudskiego Street. Another proposed solution is the introduction of roundabouts at the intersection of Piłsudskiego Street - Podwale Street - Orląt Lwowskich square and in the area shown in Figure 5. In this solution, the problem is the traffic of trams, which makes it almost impossible to implement the described proposal. To enable the introduction of roundabouts in the above-mentioned areas, it would be necessary to build a tram track on the flyovers and run bus traffic on them. This would be the most efficient solution for both tram and vehicle traffic. In the given situation, trams are excluded from the traffic light phases, which reduces the travel time in the analyzed area from Figure 1, while the use of roundabouts in these areas would significantly improve traffic conditions at all inlets. This creates a problem due to the change in the location of stops, the huge costs of the project, and the place to erect the route in each of the streets at the intersection of Piłsudskiego Street - Podwale Street- Orląt Lwowskich square.

\section{Summary}

Projects related to the construction and reconstruction of road infrastructure in Wrocław have a huge impact on traffic conditions within the city, as well as increase safety by adapting them to current standards and regulations. Currently, it is difficult to introduce any changes to the geometry of the road or intersection in the built-up area in the area of a large urban agglomeration, as the existing buildings and the established boundaries of road plots limit the possibilities of design solutions. Summarizing, the presented analysis shows how in detail it is possible to assess the individual elements influencing traffic conditions, such as the relations of inlets and outlets, the influence of traffic lights, the impact of public collective transport, throttling of relations, the relationship between intersections, the geometry of individual areas, the movement of pedestrians and bicycles.

\section{Source materials}

[1] DZIENNIK USTAW RZECZPOSPOLITEJ POLSKIEJ Warszawa, dnia 29 styczeń 2016 r. Poz. 124 OBWIESZCZENIE MINISTRA INFRASTRUKTURY I BUDOWNICTWA z dnia 23 grudnia 2015 r. "w sprawie ogłoszenia jednolitego tekstu rozporządzenia Ministra Transportu i Gospodarki Morskiej w sprawie warunków technicznych, jakim powinny odpowiadać drogi publiczne i ich usytuowanie"

[2] https://www.google.pl/maps?hl=pl

[3] Pismo nr DK - 149728/21 z dnia 02.03.2021 r. w sprawie zdarzeń drogowych w latach 2015-2020 od Komendy Miejskiej Policji we Wrocławiu Wydziału Ruchu Drogowego

[4] Pomiary natężenia godzinowe 2019.10.16 okolice Orląt od urzędu Zarządu Dróg i Utrzymania Miasta we Wrocławiu

[5] Prezentacja "Trasa Autobusowo-Tramwajowa Etap II" na stronie internetowej https://www.wroclaw.pl/portal/budujemy-tat/

[6] Szczepanek W. Praca magisterska w trakcie realizacji pt. "Poprawa bezpieczeństwa $i$ warunków ruchu na pl. Orląt Lwowskich"

[7] UCHWAŁA NR XXIII/506/16 RADY MIEJSKIEJ WROCŁAWIA z dnia 21 kwietnia 2016 r. "w sprawie uchwalenia miejscowego planu zagospodarowania przestrzennego w rejonie ulic Braniborskiej i Nabycińskiej we Wroctawiu"

[8] UCHWAŁA NR XXXIV/713/16 RADY MIASTA WROCŁAWIA z dnia 22 grudnia 2016 r. w sprawie "Planu zrównoważonego rozwoju publicznego transportu zbiorowego dla Wroctawia na lata 2016 - 2022"

[9] http://ukosne.gis.um.wroc.pl 